\title{
VIOLATIONS OF CHILDREN'S RIGHTS IN SUDAN AND THEIR CIRCUMSTANCES: THE CURRENT SITUATION AND THE POSSIBILITY OF SOLUTIONS
}

\author{
NAGMELDIN KARAMALLA-GAIBALLA ${ }^{1}$ \\ ${ }^{1}$ The University of Commerce and Services in Poznań, 28 Czerwca 1956 r., 61-485 Poznań, Poland. \\ ORCID: 0000-0001-7613-3334, Email:karamalla@gmail.com
}

\begin{abstract}
This paper aims to demonstrate the main aspects and weaknesses of children's rights in Sudan and describe how to work towards enhancing the immediate response to violations against children. This discussion will help develop future plans to strengthen the enforcement of children's rights in Sudan and create an environment that protects children's rights against all kinds of violations. This paper presents the current situation of children's rights violations in Sudan and factors that have a great and direct impact on these situations, especially social and cultural factors concerning female circumcision, genital mutilation, and marriage of underage girls; and laws that violate the dignity of Sudanese children, such as laws related to flogging, imprisonment, and death. The article also addresses issues of wars and internal conflicts and their impact on children, including their recruitment and trafficking. It also discusses the weaknesses of laws in place to protect children in Sudan and the changes these laws have undergone in recent years, especially the fundamental changes following the revolution that broke out in Sudan in 2018, which replaced the dictatorial military regime with Islamic orientations and trying to find objective solutions.

KEYWORD: Sudan, Darfur, children's rights, child labour, FGM/C, underage marriage
\end{abstract}




\section{INTRODUCTION}

The number of children exceeds half of the population. The results of the Fifth

1 Population Census in 2008 showed that the number of children under the age of 18, according to the definition of the Child Law of 2010, reached 15.5 million, representing $50 \%$ of the population in Sudan, compared to their number of 10.9 million in 1990 (Ahmed 2018).

Statistical estimates indicate that the number of children in 2018 has reached 20.9 million, and it is expected that the number will increase to 24.7 million children in 2025 and 27.1 million children in 2030 (See: Voluntary National Review 2018). These high numbers and steady increases indicate that childhood is growing at a rate of $2.4 \%$. annually. This is due to the increase in fertility rates, especially in rural areas (Cuninghame, Mubarak, \& Hosen Mohamed Farah 2016).

These growth projections do not mean that children in Sudan will enjoy prosperity, progress, and development. However, they will face many difficulties and obstacles due to the steady increase in the number of children from 20.4 million in 2018 to 27.1 million in 2030, accompanied by stability and urban and rural expansion. This situation will lead to an increase in the demand for education and health services and development, care, and protection services (United Nations 2019).

Among the expected difficulties is the increase in security threats to the safety and development of children, the most important of which are the safety of food and medicine, intellectual and cultural conquest, the spread of drugs of all kinds, the asylum of children and women from neighbouring countries, and human trafficking. All these are among the factors that threaten the well-being of children in Sudan (UN 2019).

The current reality of children in Sudan is fraught with violations of their human rights. The conditions of children in Sudan are not hidden from anyone, not only through reports and the media, but they are crystal clear through observations and daily scenes in the street and in various social services institutions such as health, education, and social services, and the annual budgets of the state. Violations of children's rights in Sudan are visible and pose ethical challenges to the campaign of responsibility towards children, and this reflects the weak role of children's rights mechanisms that prevent and respond to abuse, neglect, exploitation, violence, and discrimination against children and other violations, as evidenced by the absence of monitoring and accountability when violations occur or by not responding to dangers. Related to protection, there is also an absence of an environment that promotes and advances children's rights (Palmqvist 2006).

\section{PREVIOUS STUDIES AND DIFFICULTIES FACING RESEARCHERS}

Studies of the child's rights and the laws that regulate the rights of the child in Sudan mainly rely on the open interview method as a primary tool for data collection. These interviews usually ask a number of questions related to the development of children's laws, focusing on the tasks and responsibilities of official institutions and voluntary organizations in relation to the protection of children and the role of the law in protecting them through the function and functions of these institutions and 
organizations of all kinds and individuals interested in and their participation in child protection (Tostensen et al. 2011). In this respect, "the ethical aspects (...) as well as the limits of such research come as particularly important issues" (Markowska-Manista 2018: 63), focusing especially on children's rights in Sudan. It should be noted that these issues are not widely articulated nor treated as crucial elements of such important research challenges as children's rights and their protection.

Among other difficulties facing researchers in their study on the child's rights in Sudan is the lack of references for children's laws due to the absence of laws specifically for children (except in recent years). Consequently, researchers tend to rely on volumes of Sudan's laws to collect texts on children in other laws and then on workshops (United States Department of State 2017). Child rights working papers and brochures are also used. One of the difficulties facing researchers in their field studies is the multiplicity of agencies. It is necessary to visit their sites, gather information about them, and conduct interviews with some of their workers in all of Sudan's distant cities regarding the difficulty of transportation. There is also great difficulty in obtaining statistics, especially from the Sudanese government agencies, regarding study cases under the pretext that this information is confidential. It is forbidden to extract this information from within the body or institution (Al-Aqib Hasab Alrasul 2009).

Many studies have been conducted in Sudan regarding the protection of children's rights and related laws. Imam Muhammad's (2005) comparative study in light of international conventions deals with the traditional and evolving concept of criminal policy and asks what the criminal policy goals are? His study also dealt with criminology and criminal policy and reviewed the historical background of criminal policy in Sudan in different periods, from the formation of the Sudanese state until after independence in 1956.

Muhammad's (2005) study was exposed to care institutions in Sudan, where the researcher was exposed to the introduction of several opinions in various justice institutions that have a direct relationship to juveniles, the role of education or reformatories, and so on, and how children are placed in those homes. The researcher concluded a study that these institutions do not serve the purpose they were established, which is discipline and reform. Besides, these institutions are considered the last resort in the measure because many juveniles are deposited for minor crimes or need community care more than society's isolation. In addition to the effects of the social and economic crisis, war and poverty are major causes of juvenile crime, and thus placing the juvenile in the role of education does not change the degree of their deviation. The rehabilitation programs have been suspended for a long time, and they have not kept pace with global developments and methods of care (Tamashiro 2010).

Ahmed Al-Tayeb's (2005) study on the reform and rehabilitation programs, and their impact on modifying juvenile delinquency in Sudan following international standards, focused on the explanatory reasons for deviant behaviour and examined the factors that lead to juvenile delinquency. He asked how to prevent and treat juvenile delinquency. He also dealt with the emergence and development of the role of education and treatment of children in international legislation within the framework of the legal and institutional protection of juveniles, as well as the treatment of 
children according to the Islamic approach, exposure to reform policies and aftercare for delinquent juveniles, the practice of social and psychological work within those institutions that care for juveniles, and the appropriate and followed-up correctional and rehabilitation programs. He concluded that the lack of material and human capabilities and training prevent the success of juveniles' reform and rehabilitation programs. He recommended that the authorities provide them with qualified cadres while providing training opportunities in various fields of childhood.

Hasab Alrasul Al-Jack's (2002) study dealt with the rights of the Sudanese child regarding child labour and employment in Khartoum State, including a statistical study of child labour in Sudan (Khartoum), a comparison with international statistics, and a study of the population census in Sudan. Al-Jack (2002) studied the monitoring and analysis of child labour in different age groups and the extent of its impact on the child in terms of health and growth, their exposure to criminal activities, deprivation of the right to education, and their exposure to the worst types of exploitation. This study also compared international conventions on the child's rights with Sudanese laws and examined the weakness of their mechanisms for implementing legislation for children.

Several studies have dealt with children exploited in hard labour, employed, or deprived of education and the exercise of their fundamental rights in some articles. Several international treaties on child labour and some crucial laws were issued to minors in 1997. They concluded that these laws are not sufficient to protect the child and address their issues. There is no detail of local laws and international agreements on child labour.

Abdullah Mohamed (2000) presented the causes of homelessness and its negative effects. He examined the types of homelessness and methods of polarization to address homelessness, the vision in the future to address this phenomenon that occurred in Sudanese society during the last two decades. This study found that the philosophy on which the institutional treatment relied is mainly focused on providing a normal life for the homeless and helping them develop solutions to their problems. However, it is unclear if these children and their values can be understood-do we impose our values on them? Moreover, will they return to society?

\section{CHALLENGES IN CHILD PROTECTION IN SUDAN}

According to the latest UNESCO reports, despite the positive changes that have taken place in recent years, Sudan still faces several challenges in terms of child protection. More than 33\% of children under the age of five are not registered at birth in Sudan, and these children face difficulties in enrolling in school. There are also significant discrepancies in birth certificates between states (30.9\% in Central Darfur compared with 98.3\% in North Darfur) (Bhatia et al. 2017).

Many children are not living with their families, mainly attributed to armed conflict, displacement, and poverty. Only $82 \%$ of children in the $0-17$ age group live in a family environment, with $3.5 \%$ of them living with only one parent. This percentage does not include homeless children, who are involved in armed groups, who are in- 
volved in child labour such as gold mines, or who live in institutions (UNICEF 2020).

The abandonment of children born out of wedlock is another major challenge, as three-quarters of children are delivered every day to the only residential care facility in the country (more: Bérenger and Verdier-Chouchane 2015). In 2009, about half of the Khartoum displaced children died before they could receive treatment, while most of the survivors were adopted under the Islamic adoption system. In addition, a quarter of children in Sudan participate in child labour, as the proportion of child labour is higher among the poorest, rural, unaccompanied, and separated children. There is significant variation between states (49.4\% in East Darfur and 11.2\% in the Nile River region). Child labour is associated with poverty, insufficient social protection and services, and school dropout rates (UNICEF 2020).

\section{LAWS REGARDING DEATH SENTENCES, IMPRISONMENT, AND FLOGGING OF CHILDREN}

About 100 Sudanese children are awaiting execution. In Sudan, a special law for children has been in place since 2010. However, this law has been almost idle, and there has not been a positive change in the reality of Sudanese child protection. The reason for this is the legal inconsistency in the definition of the child, and the power of criminal law and its vague texts, especially in determining the age of criminal responsibility (McVeigh 2018).

The dominance of the 1991 Criminal Law with all its loopholes and its adoption by the judicial organs and the courts, without observing the provisions of the Child Law, led to a disruptive situation in which 100 children are now facing death sentences, in addition to five others under final implementation. Although Sudan signed the Child Law Convention of 1991, measures were not taken to harmonize domestic laws with the convention (OHCHR 2007). The observations and comments received from the ICRC and the relevant local and regional organizations regarding Sudan's report on children's rights were not considered. This situation exacerbated the injustice that children continued to suffer due to the waste of their natural and legal right to justice. However, there is a package of proposals for amendments to the Sudanese criminal law, submitted by the Child Welfare Council in Sudan, approved by the current cabinet, and awaiting approval by the Sovereignty Council and the Council of Ministers, which now constitute the legislative authority (Fadil 2019).

The ratification of these amendments allows for reviewing of death sentences and amending the charges against children in Sudan. The proposed amendments include stopping the execution of children under the age of 18, adopting this age as a criterion for defining the child, and raising the minimum for criminal responsibility to 12 years instead of 7 years, in accordance with the recommendation of the International Committee on the Rights of the Child, and in line with the measures specified by the Child Law of 2010 to deal with misdemeanours (Limon 2020).

According to the proposals, the punishment of flogging children stipulated in the Criminal Code will be abolished and replaced by measures that are not freedom-negative or degrading to human dignity, such as community service and enrollment in ap- 
propriate professional, cultural, sports, and social training courses. The amendments suggest alternative penalties for imprisoning mothers with children under the age of five and pregnant and lactating women for other than serious crimes. The proposals give the prosecution or court the right to refer delinquent children to institutional bodies. The amendments include removing any consideration of children's consent in the event of female genital mutilation or any harm resulting from any form of violence (Sadek 2020).

\section{CHILDREN'S RIGHTS DURING CONFLICTS IN SUDAN}

The conflict has had a particularly devastating impact on children. The United Nations Task Force on Monitoring and Reporting about Children in Armed Conflict has documented 194 incidents related to grave violations against children by armed groups and state security services, including the recruitment and use of children in combat and auxiliary roles as porters, cooks, and spies; killings; and mutilation, rape, and other forms of sexual violence and abduction. The task force also recorded 13 incidents in which schools were seized for military purposes, in addition to five attacks on schools (Markowska-Manista 2019).

Despite the release of at least 150 children from armed groups and the army during the year, armed groups and government forces abducted children. They recruited them as fighters to increase their numbers before placing them in camps to gather government and opposition soldiers in separate specific locations. In the Darfur region, around two million people have been forced from their land and live-in displacement camps in western Sudan. More than one million of them are children under 18, with 320,000 aged five and under (UNICEF 2005).

Children, especially boys, take an active part in armed conflict (see: Aptel 2018). Children in detention have reached $238 / 100,000$ children out of the total number of children in Sudan. Over 32,407 boys and girls across the 18 states (19,224 boys; 13,183 girls) were dealt with by law enforcement as victims, witnesses, or alleged aggressors. With the increase in referrals outside the judicial system, children with whom the law has dealt still face lengthy judicial procedures and may be placed in pretrial detention even for minor offences (UNICEF 2020).

Sudan is also considered a country of origin, transit, and destination for children. More than 2.2 million internally displaced persons and refugees from neighbouring countries and countries are affected by war. There is an increasing movement of children in Sudan due to conflict, economic pressures, child trafficking, and migration. Children who move frequently are often unaccompanied or separated from their families and are vulnerable to violence, abuse, and exploitation (Heltne et al. 2020).

\section{FEMALE CIRCUMCISION / FEMALE GENITAL MUTILATION AND UNDERAGE MARRIAGE}

Sudan is considered one of the countries in which the prevalence of this phenomenon is high. According to the 2014 Multiple Indicators Group (MICS) surveys, the preva- 
lence of FGM / C in Sudan is 87\% among women in the age group 15-49 years and 31\% among girls in the age group $0-14$ years. Female genital mutilation is a violation based on gender and a harmful social habit. Therefore, there is a need to work collectively in Sudan to abandon these harmful traditional practices, which pose risks to children's physical and psychological health and well-being (UNICEF 2020). The percentage of marriage before reaching 18 years is $38 \%$ among women in the age group from 20 to 49 years, while the percentage of women who got married before reaching the age of 15 years is $12 \%$. This matter has attracted much attention at the regional and global levels (UNICEF/RCW 2017).

According to the World Health Organization, female circumcision includes all procedures that involve partial or complete removal of the female's external genitalia or any injury to the female genital organs for non-medical reasons. This practice has no health benefits, but it may cause ongoing physical and psychological problems. A 2014 report by the United Nations Agency for Children estimated that more than $87 \%$ of Sudanese women and girls between the ages of 15 and 49 had undergone this procedure (see UNICEF 2021; AP/ABC 2020).

The states in Sudan with the highest FGM prevalence are in the north-west: North Kordofan (97.7\% of women aged 15-49), North Darfur (97.6\%), and Northern (97.5\%). The state with the lowest prevalence is Central Darfur, in the southwest, at $45.4 \%$. Women aged $15-49$ who live in rural areas are slightly more likely to undergo FGM (87.2\%) than those who live in urban areas (85.5\%). FGM is least prevalent among women aged $14-59$ with 'no education', at $76.8 \%$, and $52.8 \%$ of women aged 15-49 who have heard of FGM believe it should be discontinued (see MICS 2014) (Thiam 2016).

The first national committee to follow up on criminal law reform was established in 2006. A group of diverse groups of women joined efforts to review the law and work to criminalize female genital mutilation (Wahba 2010). In 2010 the Child Law 2010 was approved; this law introduced Article 13, which criminalizes, for the first time, female genital mutilation. In the absence of a political will, Article 13 was repealed. Since that time, six Sudanese states have passed state-by-state laws criminalizing female genital mutilation. Efforts continued, and in 2018, national laws and female circumcision laws were reviewed in the state of Khartoum. They were presented to the National Assembly and the Khartoum State Legislative Council. They were subjected to various revisions, but they were not submitted for final discussion until the parliament was dissolved in December 2018 (Tønnessen, El-Nagar, and Bamkar 2017).

The spirit of the December revolution, coupled with strong political will, paved the way for legal reforms guiding the ban on female genital mutilation. The historic step taken by the transitional government to criminalize FGM / C in Sudan, by adopting an amendment to Article 141 of the Criminal Code by the two councils, the sovereign and the ministerial, on April 22, 2020, and ratifying all the amendments proposed by the National Council for Child Welfare (NCCW) is considered a very important matter in this regard (UNFPA Sudan 2020). The abandonment of this practice is not limited to legal reform or legalization and criminalization. Instead, there is a need for serious work with local communities to help implement this law. Further efforts should be 
made to raise awareness of modification among different groups, including midwives, health service providers, parents, and youth (Wambui 2020).

\section{CONCLUSIONS}

To ensure the protection of children in Sudan, the state must ensure equality and human rights as the basis for the basic principles of children's dignity. The state must also ensure a broader and greater involvement of the main actors involved in children's approaches and all other sectors of society to enhance the role of the family and related communities (Markowska-Manista 2012).

The vision for change in Sudan is for children to be protected from violence, abuse, neglect, and exploitation. The priority is to implement an action plan for the reintegration of children associated with armed conflict and monitor, report, and respond to violations of children's rights in armed conflict situations (See: UNICEF 2018).

Addressing the root causes of migration and child trafficking is also based on addressing the root causes of the problem, not just laws, that is, working seriously to end conflicts or armed conflicts in Sudan, which are the main factor in the emergence of these negative phenomena, especially internal migration, child trafficking, and children's recruitment to fight in those wars (cf. United Nations 2008).

No child can face the death penalty or life imprisonment without the possibility of release. Children found guilty of breaking the law must be treated with dignity and respect and in a manner that considers their needs as children. The Sudanese judicial system must abide by its legal obligations by providing measures commensurate with the ages of children who commit crimes.

Ending harmful practices, predominantly female genital mutilation and child marriage in Sudan, cannot be addressed through laws and parents' criminalisation because they are linked to cultural aspects and pseudo-religious social beliefs. These practices are empowered by society, especially rural society, since these customs are sometimes transferred to societies that used not to practice these kinds of harmful behaviours. This situation happens due to social, economic, or ethnic motives, as some displaced communities see the necessity of practising the same rituals practised in the new environment to which they were displaced to be entirely accepted (Bedri and Mohammed 2020).

FUNDING: This research received no external funding.

CONFLICT OF INTEREST: The author declares no conflict of interest.

\section{REFERENCES}

Abdullah Mohamed, Hisham. 2000. “Addressing the Problem Of Homelessness: A Case 
Study to Evaluate the Experience." Higher diploma. Khartoum: Institute of African and Asian Studies, University of Khartoum.

Ahmed, A-Ali. 2018. "The Fifth Population Census in Sudan: A Census with a Full Coverage and a High Accuracy.” Khartoum: Neelain University. Retrieved December 14, 2020 (https://unstats.un.org/unsd/demographic/sources/census/countries/ SDN.pdf).

Ahmed Al-Tayeb, Al-Tayeb. 2005. "Correction and Rehabilitation Programs and Their Impact on Modifying Juvenile Delinquency in Sudan According to International Standards: A Comparative Study, Cubs Education House Al-Jarif West.” Fellowship Research. Khartoum: Higher Police Academy, Khartoum.

Al-Aqib Hasab Alrasul, Amal. 2009. "Development And Change In Child Laws And Their Social Effects In The Sudan During The Period From 1956 Until 2007.” Master's degree. Khartoum: University of Khartoum.

AP/ABC. 2020. "Sudan Moves to Ban Female Genital Mutilation with Landmark Law." Retrieved December 12, 2020 (https://www.abc.net.au/news/2020-05-03/sudanmoves-to-ban-female-genital-mutilation-with-landmark-law/12209374).

Cécile, Aptel. 2018. “The Protection Of Children In Armed Conflicts.” Pp. 1-23 in International Human Rights of Children, edited by U. Kilkelly and Liefaard Toned. Singapore: Springer. (https://doi.org/10.1007/978-981-10-3182-3 17-1).

Bedri, Nafisa, and Yussra Mohammed. 2020. "Improved Understanding of FGM/C Abandonment Among Sudanese Families in Khartoum and Kassala States." Sudan Working Paper 2: 24-25. Retrieved December 16, 2020 (https://www. cmi.no/publications/file/7315-improved-understanding-of-fgm-c-abandonment-among-sudanese-families-in-khartoum-and-kassala-states.pdf).

Bérenger, Valérie, and Audrey Verdier-Chouchane. 2015. "Child Labour and Schooling in South Sudan and Sudan: Is There a Gender Preference?” Abidjan: African Development Bank. Retrieved December 15, 2020 (http://http:/www.afdb.org).

Bhatia, Amiya, Leonardo Zanini Ferreira, Aluísio J. D. Barros, \& Cesar Gomes Victora. 2017. "Who and Where Are the Uncounted Children? Inequalities in Birth Certificate Coverage Among Children Under Five Years in 94 Countries Using Nationally Representative Household Surveys." International Journal for Equity in Health 16: 148. (https://doi.org/10.1186/s12939-017-0635-6).

Cuninghame, Chris, Abdelrahman Mubarak, \& Husam Eldin Ismail Hosen Mohamed Farah. 2016. "Child Notice Sudan." UNICEF.

Fadil, Abdullah. 2019. "Boy Sentenced to Death in Sudan for Crime Reportedly Committed as a Child.” Khartoum: UNICEF. Retrieved December 13, 2020 (https:// www.unicef.org/mena/press-releases/boy-sentenced-death-sudan-crime-reportedly-committed-child).

Hasab Alrasul Al-Jack, Manazil. 2002. "Sudanese Child Rights: A Case Study of Child Use in Khartoum State.” Postgraduate Research. Khartoum: Institute of African and Asian Studies, University of Khartoum.

Heltne, Unni Marie, Ragnhild Dybdahl, Suleima Elkhalifa, \& Anders Breidlid. 2020. "Psychosocial Support and Emergency Education: An Explorative Study of Perceptions Among Adult Stakeholders in Sudan and South Sudan.” Sustainability 
12 (1410).

Imam Muhammad, Hamid. 2005. "Criminal Policy for Juvenile Justice in Sudan: A Comparative Study in Light of International Conventions.” Doctoral degree. Khartoum: Neelain University, Department of Law.

Limon, Marc. 2020. "Human Rights in Sudan: The New Test Case for the Human Rights Council | Universal Rights Group.” Universal Rights Group. Retrieved December 15, 2020 (https://www.universal-rights.org/uncategorized/human-rights-in-sudan-the-new-test-case-for-the-human-rights-council/).

Markowska-Manista, Urszula. 2018. "The ethical dilemmas of research with children from the countries of the Global South. Whose participation?.” Polish Journal of Educational Studies 71(1): 51-65.

Markowska-Manista, Urszula. 2019. “Bad Children' International Stigmatisation Of Children Trained to Kill During War and Armed Conflict.” Pp. 61-75 in Intersectionality and Difference in Childhood and Youth. Global Perspectives, edited by N. von Benzon and C. Wilkinson. London \& New York: Routledge. DOI: $10.4324 / 9780429466588$

Markowska-Manista Urszula. 2012. „Dzieci - ofiary, świadkowie i sprawcy ludobójstw w krajach Afryki Subsaharyjskiej.” Pp. 204-224 in Auschwitz a zbrodnie ludobójstwa XX wieku, edited by A. Bartuś, P. Trojański. Oświęcim: Państwowe Muzeum Auschwitz-Birkenau, Fundacja na rzecz MDSM.

McVeigh, Karen. 2018. "South Sudan Urged to End Death Penalty as Evidence Shows Children Among Dead.” The Guardian, 7 Decmber 2018. Retrieved December 13, 2020 (https://www.theguardian.com/global-development/2018/dec/07/southsudan-urged-to-end-death-penalty-as-evidence-shows-children-among-deadamnesty-international).

MICS. 2014. Prevalence of FGM in Sudan by state. Retrieved February 15, 2021 (https:// www.28toomany.org/static/media/uploads/Country\%20Research\%20and\%20 Resources/Sudan/sudan_prevalence_map_(june_2017).png).

OHCHR. 2007. "Committee on Rights of Child Examines Report of Sudan on Sale of Children, Child Prostitution and Child Pornography.” Khartoum: UN Office of the High Commissioner for Human Rights. Retrieved December 12, 2020 (https://reliefweb.int/report/sudan/committee-rights-child-examines-report-sudan-salechildren-child-prostitution-and-child).

Palmqvist, Eva. 2006. “Children's Rights in The Sudan - An Analysis Based on the CRC Reports.” Nairobi: Save the Children Sweden. Retrieved December 15, 2020 (https://resourcecentre.savethechildren.net/node/6444/pdf/6444.pdf).

Sadek, George. 2020. "Sudan: New Law Amending Penal Code Takes Effect | Global Legal Monitor.” Loc.gov. Retrieved December 15, 2020 (https://www.loc.gov/law/ foreign-news/article/sudan-new-law-amending-penal-code-takes-effect/).

Tamashiro, Tami. 2010. “Impact of Conflict on Children's Health and Disability”. UNESCO. Retrieved December 17, 2020 (https://unesdoc.unesco.org/ark:/48223/ pf0000190712).

Thiam, Macoumba. 2016. "Female Genital Mutilation/Cutting (FGM/C) and Child Marriage in Sudan - Are There any Changes Taking Place?” Khartoum: UNICEF. Re- 
trieved December 13, 2020 (https://www.unicef.org/sudan/media/1071/file/Female-Genital-Mutilation-Cutting-Child-Marriage-Sudan-2016.pdf).

Tønnessen, Liv, Samia El-Nagar, \& Sharifa Bamkar. 2017. “Paper Tiger Law Forbidding FGM in Sudan." CMI Brief 16(4): 1-4.

Tostensen, Arne, Hugo Stokke, Sven Trygged, \& Kate Halvorsen. 2011. Supporting Child Rights. Stockholm: Sida and Norad. Retrieved December 9, 2020 (https:// www.oecd.org/countries/sudan/48350333.pdf).

UNFPA Sudan. 2020. "The First Country in Africa to Outlaw the Practice of Female-Genital Mutilation (FGM).” Retrieved December 13, 2020 (https://sudan.unfpa.org/ en/news/first-country-africa-outlaw-practice-female-genital-mutilation-fgm).

UNICEF. 2005. “Darfur Child Alert.” UNICEF.

UNICEF. 2018. "Strategy Notes of Sudan CPD 2018-2021 - UNICEF." Khartoum: UNICEF. Retrieved December 16, 2020 (http://files.unicef.org/transparency/documents/2017\%20Sudan\%20PSN\%20Child\%20Protection\%20TOC.pdf).

UNICEF. 2020. "Child Protection.” Khartoum: unicef.org. Retrieved December 14, 2020 (https://www.unicef.org/sudan/child-protection).

UNICEF. 2020. “Female Genital Mutilation (FGM).” Khartoum: UNICEF. Retrieved November 4, 2020 (https://www.unicef.org/sudan/media/2811/file/UNICEF\%20 Sudan\%20Fact\%20Sheet\%20-\%20Female\%20Genital\%20Mutilation\%20(FGM). pdf).

UNICEF. 2021. Fgm-map. Retrieved February 15, 2021 (https://blogs.unicef.org/blog/ five-things-you-didnt-know-about-female-genital-mutilationcutting-2/fgmmap/).

UNICEF/RCW. 2017. "SUDAN - Regional Study on Child Marriage." Amman: UNICEF. Retrieved December 15, 2020 (https://www.unicef.org/mena/media/1816/file/ MENA-CMReport-SudanBrief.pdf.pdf).

United Nations. 2008. “Toolkit to Combat Trafficking in Persons.” Vienna: United Nations. Retrieved December 15, 2020 (https://ec.europa.eu/anti-trafficking/sites/ antitrafficking/files/unodc_toolkit_en_1.pdf).

United Nations. 2019. "World Urbanization Prospects." New York: Department of Economic and Social Affairs Population Division. Retrieved December 12, 2020 (https://population.un.org/wup/Publications/Files/WUP2018-Report.pdf).

US Department of State. 2017. 2016 Country Reports on Human Rights Practices. Washington DC: Department of State. Retrieved December 27, 2020 (https://www.refworld.org/docid/58ec89c54.html).

Voluntary National Review (VNR). 2018. "Implementation of Agenda 2030 and the SDGs for Peace and Development in the Sudan.” Khartoum. Retrieved December 15, 2020 (https://sustainabledevelopment.un.org/content/documents/19424Sudan_Voluntary_National_Review_2018_1.pdf).

Wahba, Yasmine. 2010. "Legislative Reform to Support the Abandonment of Female Genital Mutilation/Cutting.” UNICEF. Retrieved December 15, 2020 (https:// www.unicef.org/policyanalysis/files/UNICEF__LRI_Legislative_Reform_to_support the _Abandonment_of_FGMC_August_2010.pdf).

Wambui, Evelyn. 2020. “Sudan's Decision to Criminalize Female Genital Mutilation/ 
Cutting (FGM/C) Is a Giant Step for Girls' and Women's Rights.” Khartoum: OCHA. Retrieved December 2, 2020 (https://reliefweb.int/report/sudan/sudan-s-decision-criminalise-female-genital-mutilationcutting-fgmc-giant-step-girls-and).

\section{BIOGRAPHICAL NOTE}

Nagmeldin Karamalla-Gaiballa is an economist and public finance specialist at The University of Commerce and Services in Poznań, Poland.

OPEN ACCESS: This article is distributed under the terms of the Creative Commons Attribution Non-commercial License (CC BY-NC 4.0) which permits any non-commercial use, and reproduction in any medium, provided the original author(s) and source are credited.

ARTICLE HISTORY: Received 2021-01-06 / Accepted 2021-03-27 